\title{
THE CORRELATION BETWEEN STUDENTS' MOTIVATION AND ANXIETY IN SPEAKING AT SMPN 3 JANAPRIA
}

\author{
Muh Madyan Sufyan Hadi; Tri Setianingsih; I Made Permadi Utama \\ madyanmuh@gmail.com; trisetianingsih@ikipmataram.ac.id; permadi_utama@ikipmataram.ac.id \\ Pendidikan Bahasa Inggris, FPBS IKIP Mataram
}

\begin{abstract}
This study is generally attempted to find out whether there is or there is not the correlation between students' motivation and anxiety in speaking for second grade students of SMPN 3 Janapria in academic year 2018/2019. The method of this research was applied correlative research. The population of this research was second grade students of SMPN 3 Janapria which consisted of 22 students, 11 male and 11 female. The technique which used to analysis the data was test formula. From the result of the data found out the score ofr count $=0,334$. If the error level is set in $5 \%$, and $\mathrm{N}=22$ so the $\mathrm{r}$ table $=0,423$. It means $\mathrm{r}$ count is lower than $\mathrm{r}$ table or $0,334 \leq$ 0,423 . Therefore the alternative hypothesis is rejected. In other word there is no significant correlation between students'motivation and anxiety in speaking for second grade students of SMPN 3 Janapria.
\end{abstract}

Key Words: Motivation, Anxiety, Speaking.

\section{INTRODUCTION}

Speaking is one of skill that has important role in teaching English. The people's ability in English can be seen from their speaking skill. According to Harmer (2001: 270) speaking is important in communication especially in only English. Speaking skill is always needed to communicate with other people in the world. So that way, speaking skillis important to learn. Moreover,in real life many learners think if the people who get success in speaking surely they get success in learning English because they think the first aim in learning English is to be successful in speaking.

In speaking, motivation also takes an important role. According to Harmer (1993: 3) "motivation is some kind of internal drive that encourages somebody to pursue a course of action." It means that if one wishes to achieve a goal and if that goal is sufficiently attractive, he will be strongly motivated to do whatever in necessary to reach the goal. For example, a student is motivated to learn language because he wishes to get a better job become a member of the target language community.

Therefore, if the students are less in motivation, the students don't have a goal in learning especially in learning English, they just play with their friends without give attention to their teacher. While anxiety is feeling that appears when they worry, nervous, fearful in unsuitable situation. Because most of them when they try to speak English in front of the class, student get high anxiety automatically the student will be difficult to speak well, worry,nervous, and stress that many students experience when learning a second language, but also when anxiety of student is low, automatically the student will be active, comfort and enjoy in speaking.According to Dixon (2015: 5) anxiety is an essential part of human make up. A survival instinct honed over millions of years of evaluation, it involves a series responses and reflexes that help us to avoid or deal with dangerous situation.

Based on the explanation above, the researcher is interested to conduct the 
research entitled the correlation between the students' motivation and anxiety in speaking at SMPN 3 Janapria in academic year 2018/2019.

Based on the statement of the problem, the purpose of the study is to find out the correlation between students' motivation and anxiety in speaking at SMPN 3 Janapria.This research provides two of significances, there were theoretically and practically. (1) Theoretically. (a) to the next researcher. The result of this study is hopefully could be the source or reference of information for the next researcher. (b) to the reader. The result of this study hopefully could be gave theoretical information about the correlation between students' motivation and anxiety in speaking. (2) Practically. (a) to the teacher. The result of this study hopefully would useful for English teacher to provide the important information about the more appropriate strategy that use in teaching speaking skill to the student. (b) to the students. The result of this study hopefully could create students' high motivation and less of their anxiety in speaking. Hopefully the students can speak without any worry, nervous, and stress anymore.

\section{Motivation}

According to Williams and Burden (1997: 120) in Harmer (2001: 51) suggest that motivation is a state of cognitive arousal which provokes a decision to act, as a result of which there is sustained intellectual or physical effort so that the person can achieve some previously set goal. It means that if someone wishes to achieve a goal and if that goal is sufficiently attractive, he will be strongly motivated to do whatever is necessary to reach the goal. According to Jere (2010:3) motivation is theory construct used to explain the initiation, direction, intensity, persistence, and quality of behavior especially goal directed behavior.
Based on the conception of motivation above, it can conclude that motivation from someone to do something because there is strong desire to get result from the work. Motivation in learning also can be divided into two factors that can influence motivation of the learners in learning English and increase their motivation to know more about English.

In this research the researcher shows four indicators of motivation, there were: (1) competence. The students' believes he or she has the ability to complete the task. (2) control. The students' feels in control by seeing a direct link between his and her action and an outcome. The students' retains autonomy by having some choice about whether or how to undertake the task. (3) interest. The students' have some interest in the task or sees the value of completing it. (4) relatedness. Completing the task brings the students' social rewards, such as a sense of belonging to a classroom or other desired social group or approval from a person of social importance to the students.

\section{Anxiety}

According to Dixon (2012:5) Anxiety is an essential part of being human. Anxiety is a survival mechanism that has evolved over millions of years. It involves a series of responses and reflexes that prepare us to avoid or deal with danger. This is why we have anxiety to prevent us from getting hurt.

Regarding speak in a foreign language, most of the students experienced a feeling of anxiety in the process of learning a foreign language. As argued by many theorists about the phenomena of anxiety. Maclntyre and Garden (1989) view that anxiety as feeling of worry and emotional reaction that arises while learning and using a second language.

However, the anxiety experienced is related to language anxiety. Language anxiety is viewed as one of the hindrances 
for language learners from their successful achievement in a high level of proficiency in a foreign language. (Horwitz, (2010) cited in Kondo, 2007:130). Furthermore, he also stated that language anxiety is restricted only to speaking and listening in the situation where learners communicate spontaneously in their second language.

According to Worde (2003), more than half a foreign language learners experienced some degree of anxiety. It is also argued that language learning anxiety may pose potential problems for language learners, Kondo (2009). In other words, learners who feel anxious in their foreign language may find their study less enjoyable. Moreover, he also added that the learners who feel anxious may have problems such as reduced words production and difficulty in understanding spoken instruction. In addition, Tanver (2007: 5) says that learners of English language often express a feeling of stress, nervousness or anxiety while learning to speak English and claim to have a ,mental block $^{\text {ee }}$ against learning English.

The fact that anxiety plays an important in learners ${ }^{\text {ee }}$ learning a foreign language, yet, paying attention to the factors of learning should be taken into consideration. Horwitz (1991, cited in Juhana 2010: 46), believes that anxiety about speaking a certain language can affect students ${ }^{\text {ee }}$ performance. It can influence the quality of oral language production and makes individual appear less fluent than they really are. This explanation suggests that teacher may consciously create a communal and friendly atmosphere, and may also suggest the students take a proactive role in creating such an environment.

Antonio and Diclemente (2015:13) state five indicators of reducing anxiety in speaking English those indicators were: (1) Symptom/ Situational. General nervousness in public situations is the situation where the student got nervous in front of many people. It can be seen from students are stammering when they are speaking and also interferes students ability to concentrate on the task hand. (2) Maladaptive Cognitions. Dumb and retarded is the way to think make student afraid with their ability. In this case, the students make a lot of negative selfstatements and is constantly evaluating their performance. (3) Interpersonal Conflicts. Communication problems is kind of problem student afraid to ask with each other. The students just expressionless although they do not know nothing. (4) Family Systems. Problems with in-laws is student always think about something can't be found solution, will got punishment. It can be seen from the students are afraid to express their idea, they think their idea always wrong. (5) Intrapersonal Conflicts. Low self-esteem is the problem that student cannot be motivated them selves. The students ignore their lesson and do not want to try to know what they do not know.

\section{Speaking}

Richard (2008: 19) states that the mastery of speaking skill in English is a priority for many second- language or foreign- language learners. Consequently, learners often evaluate their success in language learning as well as the effectiveness of their English course on the basis of how much they feel they have improve their spoken language proficiency.

Brown (2004: 140) stated that speaking is a productive skill that can be directly and empirically observed; those observations are invariably collared by the accuracy and fluency. While, they also stated that speaking is the product of creative construction of linguistic strings, the speakers make choices of lexicon, structure, and discourse.

Based on the definitions above, it can be inferred that speaking is a basic of 
person skill to produce language that has meaning and be understood by other people about what the speaker says. It is a skill of speaker to give information to a listener or group of listeners by transfer it effectively and speaking activity must be set on fun situation. To conclude, speaking is an activity that can express thoughts, idea and opinions orally to responds to the verbal and non verbal information.

According to Hughes (2003:100) in handout of ELT Material Development by Imran \&Sumarni (2016: 34) states that, there were five indicators in assessing speaking those indicatorswere: (1) Grammar, Confident control of the grammar is able to speak the language with sufficient structural accuracy. (2) Vocabulary, Has a speaking vocabulary sufficient to express him simply with some circumlocutions, able to speak the language with sufficient vocabulary in conversation. (3) Pronunciacion, can be intelligible though good spelling, dealing with foreigners attempting to speak his language. (4) Fluency, can discuss particular interest of competence, able to use the language fluently on all levels, can participate in any conversation with fluency. (5) Conprehension, understanding a normal rate of speech, can understand questions and statement with paraphrase, can get the gist of most conversation of non-technical subject.

\section{METHOD}

This research is a correlative study which is part of quantitative research. Quantitative research is kind of research which tend to collect in percent the data in form of numeric statistical. According to Kothari (2004: 3) quantitative research is based on the measurement of quantity or amount. While Sugiyono (2013:7) stated that quantitative approach is scientific method, because the scientific principle those are concrete or empirical, objective, measurable, rational, and systematic. This method is called quantitative approach because the research data in the form of numbers and analysis using statistics.

Therefore, the researcher used correlation design. According to Creswell (2008: 356) correlation research, the researcher uses a correlation statistical technique to describe and measure the degree of association (or relationship) between to or more variables or sets of score. In this research consist of two variables, motivation as variable $\mathrm{X}$ and anxiety in speaking as variable $\mathrm{Y}$, the researcher gave the students questionnaire sheet consist of 30 statement to tested the students' motivation and anxiety in speaking test with asked the students make a groupand each group consist of 2 students than the researcher gave the topic and the students come in front of the class to had conversation with their group in maximally 2 minutes while the researcher recorded the students conversation.

According to Miller (2005:53) a population is defined as collection of all the possible object, people or scores of a particular type. The population of this research is the second grade of SMPN3 Janapria in academic year 2018/2019. It consists of one class there is VIII A, with 22 total number of students, consist of 11 male and 11female.Sample and Sampling technique. Sampling technique is a technique of taking sample to determine the sample to be used in research (Sugiyono, 2017:118). In selecting the students as the sample, the researcher using population sampling technique.In this study, researchers chose class VIII A as a sample consists of 22 students.

The research instrument is a tool to measure the value of the variables studied. In this research, the researcher used speaking test, recording, questionnaires as the research instruments to collecting data. (1) Anxiety in Speaking test. In this research, speaking test served as the research instrument. It wasused to reveal 
the students anxiety in speaking level.By this students' speaking activity, the researcher assessed the students'anxiety in speaking level. (2) Recording. Recording is an instrument that used by researcher to recorded the students' speaking to know their anxiety in speaking. In collecting the data by using sound record, the researcher gave maximally 2 minutes to record the students when they were speaking, the researcherrecorded each of the students when they were having conversation with their friends about the topic that the researcher gave them. (3) Questionnaire. There were questionnaire sheet for testing students' motivation. The student was given a paper sheet by the researcher. The researcher guided them to fulfill the statements.

Anxiety in speaking test was done to know the students' anxiety in speaking. The researcher asks the students having conversation with their partner while the researcher observes the students' anxiety in speaking. The next teps was recording. In collecting the data by using sound record, the researcher gave maximally 2 minutes to record the students when they were speaking, the researcherrecorded each of the students when they were having conversation with their friends about the topic that the researcher gave them. The las was questionnaire. There was questionnaire sheet for testing students' motivation. The students was given a paper sheet by the researcher, they had to answered or fulfill the statements, the students did not doing interaction with their partner during fulfill the statement with controlled by the researcher, the researcher guided them in fulfill the statements.

Based on the research design, the obtained data would be analyzed by correlation product moment. $r_{x y}=\frac{\sum x y}{\sqrt{\sum x^{2} y^{2}}}$

Where: $r_{x y} \quad=$ The correlation between variable $X$ and variable $Y$

$$
\begin{array}{ll}
x & =(\mathrm{X}-\mathrm{MX}) \\
\mathrm{y} & =(\mathrm{Y}-\mathrm{MY})
\end{array}
$$

\section{RESEARCH FINDING AND DISCUSSIONS}

The data collected from the eight grade students of SMPN 3 Janapria in academic year 2017/2018, there were 22 students consist of 11 male and 11 female tested to describe the result of questionnaire ofs motivation. The researcher gave the students a paper sheet, the students have to answered or fulfill the statements, the researcher guide them in fulfill the statement. The students do not interact with their friends when they fulfill the statements. The questionnaire of motivation consist of 30 items, Anxiety in speaking test is done to know the students' anxiety in speaking, the researcher asked the students make a group and each group consist of 2 students and make conversation about planning a trip for holiday, after that the researcher ask the group one by one to have conversation in front of the class in maximally 2 minutes, while the researcher recorded the students speaking when the students having conversation. (1) The result of questionnaire of motivation. The questionnaire of motivation consisted of 30 items related to the students' motivation, the researcher gave the students a paper sheet to fulfill and the researcher guide the students when the students fulfill the statement the result of questionnaire of motivation described on the following table below:

The result of questionnaire of motivation explain that from 22 students, there are7 students with higher score from $100,101,102,103,104,105$, and the others get score from 87 to 98 , and the total of all scores from 22 students is 2131 . (2) The result of anxiety in speaking test. The result of anxiety in speaking test 
gained from the students' speaking by recorded their conversation about planning a trip for holiday when the researcher took in the class. The researcher gave the student's time about 2 minutes to had conversation with their partner and then the researcher input into the. The result of anxiety in speaking test described on the following below:

The result of anxiety in speaking test explained that from 22 students' only one student with score $\geq 70$ that is 71 than the other students with score $\leq 70$ that is from 50 to 69 , and the total of all scores from 22 students is 1334. (3) The result of correlation between students' motivation and anxiety in speaking.

The result of correlation between students' motivation and anxiety in speaking, researcher knows that $x=\mathrm{MX}$ $\mathrm{X}$, the total score of variable $x$ (motivation) $=618,591$ mean score of $\mathrm{X}=$ 2131:22 $=96,86$. Than $y=$ MY-Y, the total score of variable $y$ (anxiety in speaking) $=1516,09$, the mean score of $\mathrm{Y}=1334: 22=60,63$. The total score of $x^{2}$ $=\sum x^{2}=618,591$. The total score of $y^{2}=$ $\sum y^{2}=1516,09$. Than the last the total score of $x$ variable multiplied $y$ variable $=$ $\sum x y=323,892$.

To find out the result of the correlation between students' motivation and anxiety in speaking, the researcher uses the following formula:

$$
\begin{aligned}
& r_{x y}=\frac{\sum x y}{\sqrt{\sum x^{2} y^{2}}} \\
& r_{x y}=\frac{323,892}{\sqrt{\sum 618_{z}, 591.1516_{2}, 09}} \\
& r_{x y}=\frac{323,892}{\sqrt{937.839,629}}=\frac{323_{\imath}, 892}{968_{2}, 421}=0,334
\end{aligned}
$$

From the result above, the researcher found $r$ count $=0,334$. If the error level is set in $5 \%$, and $\mathrm{N}=22$ so the $\mathrm{r}$ table $=0,423$. It means $r$ count is lower than $r$ table or $0,334 \leq 0,423$. Therefore the alternative hypothesis is rejected. In other word there is no significant correlation between students'motivation and anxiety in speaking for second grade students of SMPN 3 Janapria.

In this session, the researcher wants to explain in detail about some of findings on research findings. The researcher wants to explain findings about score of questionnaire of students' motivation. The researcher found there were 7 students with higher score from 100, 101, 102, 103, 104,105 , and the others get score from 87 to 98 , and the total of all scores from 22 students is 2131. About anxiety in speaking test, the researcher found only one student with score $\geq 70$ that is 71 than the other students with score $\leq 70$ that is from 50 to 69 , and the total of all scores from 22 students is 1334 .

Huyen (2003), Boonkit (2010), Liu (2011), and others mention other common factors causing student' anxiety includes lack of vocabulary, lack of confidence, fear of making mistakes and being laughed at, lack of preparation and shyness. Those factors that causing anxiety because of the students' less of motivation, therefore when the students have high of motivation, they looked for the vocabulary themselves and got their self confidence than didn't fear of making mistake and less of shyness.

The researcher found out the result of correlation between students' motivation and anxiety in speaking was 0,334. According to Sugiyono (2017: 231), 0,334 were in interval coefficient 0,200 0,399 . It means the correlation between students' motivation and anxiety in speaking at SMPN 3 Janapria in academic year 2018/2019 was in interpretation low.

The researcher also found $\mathrm{r}$ count $=$ 0,334 and $r$ table $=0,423$. It means $r$ count is lower than $r$ table or $0,334 \leq 0,423$. Therefore the alternative hypothesis is rejected. In other word there is no significant correlation between students'motivation and anxiety in 
speaking for second grade students of SMPN 3 Janapria.

\section{CONCLUSION}

After the calculating the data above, the researcher knows that $x=\mathrm{MX}-\mathrm{X}$, the total score of variable $x$ (motivation) $=$ 618,591 mean score of $X=2131: 22=$ 96,86 . Than $y=$ MY-Y, the total score of variable $y$ (anxiety in speaking) $=1516,09$, the mean score of $\mathrm{Y}=1334: 22=60,63$. The total score of $x^{2}=\sum x^{2}=618,591$. The total score of $y^{2}=\sum y^{2}=1516,09$. Than the last the total score of $x$ variable multiplied $y$ variable $=\sum x y=323,892$. The researcher found that the result of $r$ count $=0,334$. If the error level is set in 5\%, and $\mathrm{N}=22$ so the $\mathrm{r}$ table $=0,423$. It means $\mathrm{r}$ count is lower than $\mathrm{r}$ table or $0,334 \leq$ 0,423 . Therefore the alternative hypothesis is rejected. In other word there is no significant correlation between students'motivation and anxiety in speaking for second grade students of SMPN 3 Janapria. The result of correlation between students' motivation and anxiety in speaking was 0,334. It means the correlation between students' motivation and anxiety in speaking was in interpretation low because 0,334 were in interval coefficient $0,200-0,399$.

\section{REFERENCES}

Antonio and Diclemente, Carlo C. 2015.More Than Anxiety: A Transtheoretical Approach. The United States of America.

Boonkit, Kamonpan. (2010). Enhancing the Development of Speaking Skill for Non-Native Speaker of English. Procedia Social and Behavioral Sciences 2 (2010) 1305-1309

Brown, H. Douglas. 2001. Teaching by Principle. Second Edition. San Francisco: San Francisco University.
2004. Language

Assessment Principle and Classroom Practices. San Francisco state University.

Creswell, John W. 2014. ResearchDesign Qualitative, Quantitative, and Mixed Methods Approaches. University of Nebraska-linclon.

Dixon, Terry. 2012. UnderstandingAnxiety Problems. Published by Help-For www.help-for.com

Ellis, Rod. (1994). The study of Second Language Acquisition. Oxford University Press.

Harmer, Jeremy. 1993. How to Teach English. Harlow: Pearson Education Limited.

Horwitz, E. K., Horwitz, M. B., \& Cope, J. (1986). Foreign language classroom anxiety. TheModern Language Journal, 70(2), 125-132.

Hughes. 2003 in Imran, and Sumarni. 2016). ELT Material Development. Mataram: IKIP Mataram.

Kondo, Yusuke. (2009). A Study on Relationship between Language Anxiety and Proficiency: In a Case Study in a Case of Japanese Learner of English. Waseda University.

Kothari, C, R. 2004. Study Methodology. Methods and Techniques( $2^{\text {nd }}$ Revised Edition). New Age International publishers.

Liu, Meihua. (2007). Anxiety in Oral English Classroom: A Case Study in China. Indonesian Journal of English Language Teaching, 3: 119-134.

MacIntyre, P.D. and Gardner, R.C. (1989).Anxiety and Second Language learning: Toward a theoretical Clarification.Language Learning, 39: 251-275 
Miller, Steve. 2005. Experimental Design and Statistics (2 $2^{\text {nd }}$ Edition). New York: Routledge.

Jere Brophy. 2004. Motivating Student to Learning. Michigan State University.

Tanveer, Muhammad. (2007). Investigation of the factors that causelanguage anxiety for ESL/EFLlearners in learning speaking skills and the influence it casts on communication in the target language.Unpublished Doctoral Dissertation.University of Glasglow. United Kingdom.

Pintrich Paul R. 2003. Motivational Science Perspective on the Role of Student Motivation In Learning and Teaching Contexts. University of Michigan.
Riasati, M. J., (2001). Language Learning Anxiety from EFL Learners ${ }^{\text {e }}$ Perspective.Middle-East Journal of Scientific Research 7(6): 907-914

Richards, J.C. 2008. Teaching Listening and Speaking. Cambridge: Cambridge University Press.

Speilberger, C.D. (1983). Anxiety.NY Academic Press.

Sugiyono.

2011.MetodePenelitianKuantitatif Kualitatif dan $R \& D$. Bandung Alfabeta

Sugiyono. 2017. MetodePenelitianKuantitatifKualit atifdan $R \& D$. Bandung: Alfabeta.

Sugiyono. 2017. StatistikUntukPenelitian. Bandung: Alfabeta. 